\title{
Memupuk Minat Baca Anak
}

\author{
Pranandia Popi Pitaloka
}

\begin{abstract}
This article discusses about fostering children's reading interest. The research method used is, looking for sources in the library (Library Research), Observation (Observation), and question and answer (Questionnaire). School libraries can be used as a source of learning for students, both in the process of teaching and learning activities in formal and non-formal ways to help schools in their efforts to achieve educational goals in the school. If the teacher's high reading interest will be easier and lighter in carrying out his duties. Children will be more active, seek and explore knowledge.
\end{abstract}

Keywords: reading interest, children, school library

\section{Pendahuluan}

Kondisi anak didik saat ini umumnya kurang menyenangi buku, minat baca tidak menonjol, dan mereka lebih suka menonton televisi. Membaca dilakukan terbatas pada buku-buku pelajaran pokok yang digunakan di sekolah. Itu pun bagaikan terpaksa, karena akan diadakan ulangan, atau karena guru memberi pekerjaan rumah. Ketekunan membaca hanya dimiliki beberapa orang anak saja di sekolah. Akibatnya pengetahuan anak sangat terbatas, penguasaan bahasa menjadi lambat bahkan kemampuan menangkap isi bacaan juga rendah. Ini harus dijadikan suatu tanda dan peringatan bagi guru dan orang tua, bahwa "minat baca" anak harus dipupuk, dikembangkan. Perpustakaan merupakan jantung atau urat nadi bagi pendidikan. Darisinilah perpustakaan harus menunjukkan fungsinya sebagai tempat untuk mengembangkan dan meningkatkan budaya membaca siswa. 
Perpustakaan tidak hanya menjadi tempat menyimpan dan mencari buku, tetapi lebih dari itu yaitu menjadi sumber/tempat mencari informasi. Setiap sekolah yang menginginkan pendidikan yang berkualitas mutlak senantiasa menumbuh kembangkan perpustakaan. Sebagaimana tertuang dalam Undang-Undang Republik Indonesia Nomor 20 Tahun 2003 tentang Sistem Pendidikan Nasional Pasal 45 (ayat 1) yang menyebutkan bahwa "Setiap satuan pendidikan formal dan non formal menyediakan sarana dan prasarana yang memenuhi keperluan pendidikan sesuai dengan pertumbuhan dan perkembangan potensi fisik, kecerdasan intelektual, sosial, emosional, dan kejiwaan peserta didik". Sarana dan prasarana yang dimaksud meliputi perpustakaan, laboratorium, dan sarana lain yang menunjang kelancaran proses belajar mengajar. Demikian pula UndangUndang No. 43 Tahun 2007 tentang Perpustakaan; dalam pasal 23 menyebutkan bahwa setiap Sekolah/Madrasah menyelenggarakan perpustakaan yang memenuhi standart nasional perpustakaan dengan memperhatikan Standart Nasional Pendidikan.

Perpustakaan sekolah memiliki peran yang strategis sebagai sumber belajar dan sumber informasi bagi warga sekolah yaitu kepala sekolah, guru, siswa dan staf administrasi dalam memperoleh kesempatan untuk memperluas dan memperdalam pengetahuan dengan membaca bahan perpustakaan yang mengandung ilmu pengetahuan yang diperlukan.

Perpustakaan merupakan sebuah lembaga yang mengelola sumber informasi yang menduduki posisi penting dalam lingkungan pendidikan dan tempat pelatihan bagi seseorang yang peduli dengan ilmu pengetahuan, baik dilingkungan sekolah maupun dilingkungan masyarakat pada umunya. Demikian juga dengan adanya perpustakaan sekolah, tujuan awal dari pendirian perpustakaan sekolah adalah sebagai sumber informasi dan pengetahuan dilingkungan sekolah dan 
juga digunakan sebagai tempat awal untuk mengembangkan minat dan budaya membaca bagi seorang siswa.

Perkembangan minat baca terutama siswa memang sangat memprihatinkan. Kebiasaan membaca harus ditanamkan sedari kecil dan akan terbawa hingga dewasa.

Kebanyakan sekolah tidak memiliki fasilitas perpustakaan yang memadai, koleksinya hanya berisi buku pelajaran umum sehingga membosankan bagi siswa. Bahkan, banyak sekolah yang tidak memiliki ruang khusus untuk perpustakaan dan tidak ada petugas khusus yang mengelola perpustakaan. Wajar saja kalau siswa tidak memiliki kebiasaan membaca yang memadai. Berbagai upaya terus dilakukan untuk dapat meningkatkan minat baca. Mengingat begitu pentingnya fungsi perpustakaan untuk membentuk siswa yang cerdas dan berkualitas maka perlu adanya pengelolaan secara profesional baik tenaga, koleksi, layanan, dan aspek lain yang terkait termasuk dalam hal pendanaannya.

Penelitian ini dilakukan di MTs Negeri 2 Jl. Perantun, Medan. Observasi dilaksanakan sekitar bulan Februari 2018. MTs N 2 Medan yang berada di bawah naungan Departemen Agama Kota Medan ini memiliki fasilitas perpustakaan dengan luas $8 \times 13 \mathrm{~m}^{2 .}$. Saat ini jumlah siswa 1310 orang dan hanya terdaftar sebagai anggota perpustakaan sekitar 578 orang. Jumlah koleksi bahan pustaka hanya sekitar 518 judul dan 370 eksemplar. Siswa dapat meminjam buku sebanyak 2 judul buku dengan lama peminjaman 1 minggu. Sistem pelayanan sirkulasi masih manual menggunakan kartu anggota. Keterlambatan akan dikenakan sanksi sebesar Rp. 500,- perhari.

\section{Tujuan Penelitian}

Tujuan penelitian ini adalah untuk mengetahui penyebab dan dampak rendahnya minat baca terutama dalam era globalisasi ini serta mengidentifikasi pentingnya membaca dalam rangka 
menambah wawasan dan pengetahuan untuk mendukung proses belajar mengajar.

\section{Rumusan Masalah}

Adapun rumusan masalah yang ingin penulis teliti adalah :

1. Apa penyebab rendahnya minat baca pada siswa ?

2. Apa dampak/ akibat dari rendahnya minat baca bagi diri sendiri, masyarakat bangsa dan negara?

3. Bagaimana cara meningkatkan minat baca siswa?

\section{Hipotesa}

Ada beberapa hal umum yang bisa disimpulkan dari pengamatan pribadi. Rendahnya minat baca pada siswa disebabkan oleh :

1. Rendahnya/tidak adanya keinginan siswa untuk menambah ilmu pengetahuan dan memperluas wawasan dengan membaca.

2. Siswa tidak mengutamakan aktivitas membaca dalam kesehariannya.

3. Tidak adanya dukungan sekolah untuk perpustakaan.

\section{Metode Penelitian}

Metode penelitian yang digunakan adalah, mencari sumber di perpustakaan (Library Research), Observasi (Observation), dan tanya jawab (Questionnaire).

\section{Populasi dan Sampel}

Populasi dari penelitian ini adalah siswa yang ada dilingkungan MTsN 2 Medan. Sedangkan sampel yang ingin diambil adalah kelas VIII P 1.

\section{Rendahnya Minat Baca Pada Siswa}

Membaca merupakan suatu proses menangkap atau memperoleh konsep-konsep yang dimaksud oleh pengarangnya, menginterpretasi, mengevaluasi konsep-konsep pengarang dan merefleksikan atau bertindak seperti yang dimaksud dalam konsep itu (Susanto, 2013). 
Darmono (2007:214) menyatakan bahwa minat baca merupakan kecenderungan jiwa yang mendorong seseorang berbuat sesuatu terhadap membaca. Minat baca ditunjukkan dengan keinginan yang kuat untuk melakukan kegiatan membaca.

Demi mewujudkan minat baca tersebut peran sekolah sangat diharapkan membantu untuk menumbuhkembangkannya melalui perpustakaan sekolah.

Perpustakaan sekolah merupakan unit kerja dan bagian integral dari lembaga pendidikan yang berupa tempat penyimpanan koleksi bahan pustaka yang dikelola dan diatur menurut sistem tertentu untuk digunakan dalam menunjang kegiatan belajar dan mengajar di sekolah dan untuk kepentingan proses pembelajaran di sekolah sesuai jenjang sekolah.

\section{Fungsi Perpustakaan Sekolah}

Menurut A.S. Nasution ( 1981 ) Perpustakaan sekolah mempunyai fungsi sebagai berikut :

1. Sebagai pusat belajar mengajar

Bagi guru dan siswa perpustakaan sekolah merupakan sarana untuk belajar, dengan tekanan pada para siswa untuk belajar mencari informasi yang berkaitan dengan mata pelajaran.

2. Sebagai pusat penelitian sederhana

Perpustakaan siswa membantu siswa melakukan penelitian perpustakaan, yang kemudian dikaitkan dengan lingkungan sekitar

3 Sebagai penambah pengetahuan dan rekreasi Perpustakaan sekolah menyediakan bahan pustaka guna pengembangan pengetahuan siswa dan guru.

4. Sebagai pusat pengembangan apresiasi budaya Perpustakaan sekolah menyediakan bahan pustaka yang mendidik siswa dan guru menghargai nilai budaya bangsa Indonesia. 
5. Sebagai media preservasi

Perpustakaan sekolah dapat untuk menyimpan dan

memelihara bahan pustaka untuk maksud melestarikan.

\section{Tujuan Pengelolaan Perpustakaan Sekolah}

Pengelolaan perpustakaan sekolah bertujuan :

1. Menyediakan buku-buku bacaan bagi siswa yang berupa buku teks maupun buku-buku umum

2. Agar siswa memperoleh informasi ilmu pengetahuan dari buku yang dibaca sehingga siswa dapat mengembangkan kemampuan dan keahliannya.

3. Membangkitkan siswa untuk gemar membaca

\section{Penyebab Rendahnya Minat Baca pada Siswa}

Rendahnya minat baca pada siswa dapat dipengaruhi oleh beberapa faktor, diantaranya sebagai berikut :

1. Lemahnya dukungan dan perhatian dari kepala sekolah

Tidak ada program dari sekolah yang dapat mendukung kegiatan yang berhubungan dengan minat baca serta alokasi dana yang kurang memadai sehingga menghambat proses pengelolaan perpustakaan. Dana sangat diperlukan dalam kegiatan perpustakaan selain pengadaan, pengolahan dan pelayanan, juga ada kegiatan perawatan dan perbaikan baik koleksi maupun sarana prasarana lainnya.

2. Kurangnya pengelolaan perpustakaan sekolah

Koleksi perpustakaan kurang menarik yang hanya berisi buku pelajaran membuat siswa malas untuk membaca. Layanan yang hanya berupa pelayanan sirkulasi yaitu layanan peminjaman, pengembalian dan perpanjangan bahan pustaka untuk dibawa pulang maupun baca ditempat. Petugas perpustakaan yang belum semua memiliki kualifikasi akademik perpustakaan terkadang hanya diisi guru bidang studi.

3. Kemajuan teknologi 
Perkembangan teknologi terutama gadget membuat anak lebih tertarik bermain gadget. Bentuknya yang fleksibel dapat dibawa kemana saja, kecil dan memiliki fitur yang banyak seperti Google, Yahoo, Youtube, game online, facebook, instagram, twiter, atau lainnya membuat informasi dari dunia mana saja dapat diketahui. Bahkan saat mengerjakan PR pun anak lebih suka menelusurnya melalui internet dari pada membaca buku.

4. Acara hiburan

Berkembangnya pusat permainan, mall, kafe, karoake, atau sejenis lainnya. Tempat yang nyaman bahkan terdapat fasilitas wifi gratis membuat mereka betah berlama-lama di area ini.

5. Acara televisi

Maraknya acara televisi yang bersifat kartun, komedi, sinetron, dan sebagainya juga membuat anak betah untuk berlama lama di depan televisi. Bahkan tayangan yang bersifat harian atau mingguan menjadi kegiatan rutinitas bagi mereka.

6. Kurangnya dukungan keluarga dan lingkungan Rendahnya minat baca di kalangan anak dapat disebabkan oleh kondisi keluarga yang tidak mendukung, terutama dari orang tua yang tidak mencontohkan kegemaran membaca kepada anak-anak mereka. Selain itu, kurangnya perhatian dan pengawasan orang tua terhadap kegiatan anakanaknya. Minimnya ketersediaan bahan bacaan di rumah juga dapat membuat anak kurang berminat pada kegiatan membaca. Selain dari sisi keluarga, terdapat juga pengaruh dari lingkungan. Karena pengaruh ajakan yang begitu kuat dari teman, anak lebih memilih bermain dengan temantemannya dibanding membaca buku. Ketersediaan waktu yang kurang, membuat anak tidak sempat membaca. 
Seperti anak yang bersekolah sampai sore hari, tentu sebagian besar waktu dalam sehari sudah banyak dihabiskan di sekolah. Kesempatan memiliki waktu luang sangat terbatas. Apalagi jika masih ada kegiatan-kegiatan rutin yang mereka jalani setelah pulang sekolah. Kalaupun masih ada sisa waktu, mereka lebih memanfaatkan untuk bersantai dan melepas lelah.

\section{Dampak / Akibat Rendahnya Minat Baca pada Siswa}

Rendahnya minat baca dapat berdampak buruk, bagi diri sendiri, masyarakat bangsa dan negara.

1. Bagi diri sendiri

Buruknya minat baca siswa berdampak pada kekurangnya kemampuan mereka dalam penguasan bidang ilmu pengetahuan dan menurunnya prestasi yang diraih,.

2. Bagi masyarakat, bangsa dan negara

Apabila rendahnya minat dan kemampuan membaca siswa, maka dalam persaingan global kita akan selalu ketinggalan dengan sesama negara berkembang, apalagi dengan negara-negara maju lainnya. Kita tidak akan mampu mengatasi segala persoalan sosial, politik, ekonomi, kebudayaan dan lainnya selama SDM kita tidak kompetitif, karena kurangnya penguasaan ilmu pengetahuan dan teknologi, akibat lemahnya kemauan membaca.

\section{Beberapa Cara Meningkatkan Minat Baca pada Siswa}

1. Dukungan dari sekolah

Diadakannya perlombaan seperti resensi buku, menulis artikel atau lainnya dapat memacu kreatifitas siswa. Bila ranking kelas sebaiknya sekolah memberikan hadiah berupa buku bacaan. Membuat perlombaan misalnya meringkas buku atau sinopsis, dengan membuat sinopsis sebenarnya siswa diajarkan untuk menuangkan gagasan ke 
dalam sebuah tulisan . Alokasi dana serta pengadaan bahan pustaka yang bermutu sesuai dengan minat dan kebutuhan siswa harus disediakan untuk menunjang keberhasilan siswa dalam proses belajar mengajar.

2.Pengelolaan perpustakaan sekolah

Salah satu fungsi perpustakaan adalah sebagai tempat rekreasi. Fungsi inilah yang belum dijalankan dalam perpustakaan sekolah. Suasana yang nyaman dan koleksi yang berisi buku cerpen, novel, cergam, majalah atau bahkan kerajinan tangan dari siswa bisa dipajang di perpustakaan tersebut. Memberi penghargaan bagi siswa yang rajin berkunjung atau siswa yang paling sering meminjam buku juga dapat menambah semangat mereka untuk berkunjung ke perpustakaan.

3. Pengawasan orangtua

Jangan berikan gadget kepada anak dibawah usia 12 tahun dan orangtua harus melakukan pengawasan terhadap apa saja yang mereka lihat di gadget. Berikan buku sebagai hadiah bila anak kita memenangkan sebuah perlombaan atau mendapat ranking di sekolah. Mengajaknya ke toko buku atau perpustakaan.

Temani anak saat akan menonton televisi dan pilihlah tontonan yang dapat membangkitkan semangat belajarnya. Rekreasi ke tempat hiburan seperti pusat permainan, menonton bioskop hanya di saat libur sekolah. Selingi kegiatan seperti bercerita, mewarnai atau melukis.

Selain peran serta guru dalam meningkatkan minat baca, orang tua pun harus berperan aktif membantu meningkatkan minat baca siswa. Dengan adanya kerja sama antara guru dan orang tua serta membuat kegiatan yang rekreatif dan edukatif diharapkan dapat membangun minat baca siswa di sekolah. Tinggi rendahnya minat baca suatu bangsa amat 
menentukan kualitas sumber daya manusia, sedangkan kualitas sumber daya manusia sangat menentukan perkembangan suatu bangsa.

\section{Penutup}

\section{Kesimpulan}

Perpustakaan sekolah dapat dijadikan sumber belajar siswa, baik dalam proses kegiatan belajar mengajar secara formal maupun non formal untuk membantu sekolah dalam upaya mencapai tujuan pendidikan di sekolah tersebut. Apabila minat baca tinggi guru akan lebih mudah dan ringan dalam melaksanakan tugasnya. Anak-anak akan lebih aktif, mencari dan menggali pengetahuan.

\section{Saran}

Pihak sekolah ikut bertanggung jawab menumbuhkan minat baca bagi siswa. Saran. kepada sekolah untuk meningkatkan minat baca siswa antara lain sekolah harus aktif membuat kegiatan yang berhubungan dengan minat baca seperti Gerbaning (Gerakan Membaca Hening), Gerbanas (Gerakan Membaca Nasional), dan lain lain. karena dari sanalah sumber kreatifitas akan muncul. Setelah membaca mereka diharapkan mampu menuliskan kesimpulan dari apa yang mereka baca.

Kalau bangsa ini mau maju dan lebih berkualitas maka harus ada upaya-upaya yang lebih konkret baik dari pemerintah maupun masyarakat untuk mendongkrak minat baca siswa. Meskipun hal ini sangat tidak mudah akan tetapi harus dilakukan.

\section{Daftar Pustaka}

Ahmad Susanto. (2013). Teori Belajar dan Pembelajaran di Sekolah Dasar. Jakarta: Kencana Prenadamedia Group.

Arikunto, Suharsimi. (2003). Prosedur Penelitian.. Jakarta: Bumi Aksara.

A.S. Nasution dkk, (1981). Perpustakaan Sekolah. Jakarta: Proyek Pengembangan Perpustakaan-Depdikbud. 
Darmono. (2007). Perpustakaan Sekolah: Pendekatan Aspek Manajemen dan Tata Kerja. Jakarta: Grasindo. 